\author{
Bartosh Olena \\ Candidate of Pedagogical Sciences, PhD, Associate Professor \\ Department of Sociology and Social Work \\ State University «Uzhhorod National University», Uzhhorod, Ukraine \\ olena.bartosh@uzhnu.edu.ua \\ ORCID ID: http://orcid.org/0000-0001-6733-5516
}

\title{
BILINGUAL INTERCULTURAL EDUCATION AS AN IMPORTANT PRECONDITION OF PROVIDING THE EFFECTIVE INTERCULTURAL INTERACTION IN THE AMERICAN MULTINATIONAL SOCIETY
}

\begin{abstract}
American scientists see the introduction of multicultural education, in particular bilingual intercultural education, as one of the promising ways of ensuring the effective intercultural interaction. The purpose of the paper is to analyse and summarise the ideas of the American experience of bilingual education as a means of ensuring the effective intercultural interaction in a multinational state. Methods of the research used: analysis and systematization of pedagogical works, which made it possible to identify conceptual considerations on the bilingual intercultural education as an important precondition of effective intercultural interaction; observations and practice of author's teaching experience used to reveal the main aspects of the issue under consideration. Scientific novelty lies in the substantiation of essential characteristics of bilingual intercultural education and its role in ensuring of intercultural interaction in a multinational society. Bilingial intercultural education is a deliberate process of engaging in the world culture by means of native and foreign languages, when a foreign language acts as a means of knowing the world, acquiring of special knowledge, mastering the cultural, historical and social experience of different countries and peoples. For domestic science and practice, it is advisable to use the ideas of foreign experience of bilingual intercultural education. We consider bilingual intercultural education as such an education organisation when it becomes possible to use more than one language as a language of teaching. The second language is thus not only an object of study, but also a means of communication and a language of teaching. The main difference between bilingual intercultural education and traditional education is that the language of teaching itself is not only a tool for teaching and learning, but also its purpose.
\end{abstract}

Key words: intercultural interaction; multinational society; bilingual intercultural education; multicultural education; foreign experience.

Introduction.. Nowadays ethnic and cultural diversity characterises many countries of the world. Unfortunately, in recent years, there has been a considerable increase in ethnic tensions, with ethnic conflicts occurring. It should be noted that ethnic conflicts accompany the whole history of mankind and the main reason for them are: the uneven development, the differences in the accessibility of social goods, the efforts to solve problems at the expense of other nations, the psychological rejection of «strangers». In this regard, among the most important priorities of its national policy the USA, one of the largest multinational countries in the world, identifies the restoration of spiritual life of ethnic communities based on establishing of favourable conditions and taking into account of their interests in language, culture, and traditions. Thus, the situation calles for the deeper study of intercultural interaction problem in a multinational state.

Analysis of recent research and publications. American scholars see the introduction of multicultural education, in particular bilingual intercultural education (BIE), as one of the promising ways of ensuring the effective intercultural interaction.

E. Hall mentions that researchers proved the complexity of human communication phenomenon in general, as well as significant differences in standards, values, perceptions, patterns of thinking and behaviour inherent in representatives of different cultures [1].

We are in favour of position of M. Hammer et al. [2], D. Nesdale et al. [3] who prove in their studies that intercultural interaction in a multinational society involves various forms of interaction between individuals, groups or organisations belonging to different cultures. Intercultural interaction is based on intercultural communication. A. Matveev and P. Nelson [4] draw attention that crucial here is the issue of cultural differences importance, their awareness, understanding and adequate consideration in the communication process. After all, the main purpose and meaning of any communication process is the desire to become undersood, which involves the need to fully convey information, knowledge and experience to an interlocutor.

An important role in preparing for the productive intercultural communication in a multinational society belongs to bilingual intercultural education, which is an integral part of multicultural education [5]. According to C. Baker [6] the effectiveness of BIE is checked at the level of: an individual child; classroom; school; programmes or geographical regions. There are various effects, such as home and parents, community, teachers, school and society that make BIE successfull.

The purpose of the study is to analyse and summarise the ideas of the american experience of bilingual intercultural education as a means of ensuring the effective intercultural interaction in a multinational state. Methods of the research applied: analysis and systematization of pedagogical works, which made it possible to identify conceptual considerations on the bilingual intercultural education as an important precondition of effective intercultural interaction; observations and practice of author's teaching experience used to reveal the main aspects of the issue under consideration.

Discussion and results. BIE is an education model designed for areas in which more than one language is spoken and the people are in contact with more that one culture. BIE is considered by researchers as a necessary tool for achieving equality. There is a tangible link between bilingual education and equality. The use of the mother tongue at school as a language of explanation and communication gives the right to students from different cultures to receive education in the language they understand best, otherwise they are not able to succeed in education and in the future profession $[7 ; 8]$.

We consider BIE as such an education organisation 
when it becomes possible to use more than one language as a language of teaching. The second language is thus not only an object of study, but also a means of communication and a language of teaching. The main difference between BIE and traditional education is that the language of teaching itself is not only a tool for teaching and learning, but also its purpose. Not only does BIE contribute to the formation of students' linguistic competence, but it is also an important means of building an educational process along the lines of cross-cultural dialogue. In some countries, BIE is also one of the main tools in the adaptation and education of minority students. This form of education is a key to building a learning process that takes into account linguistic and cultural characteristics and promotes the formation of equal educational opportunities, regardless of cultural background.

The USA differs from the usual multinational states as here intercultural interaction took place not within individual ethnic groups, but within immigrants, who came here from different countries and representated different cultural groups. As a result of constant mass immigration, representatives of many national minorities form in the USA new ethnic-cultural groups and specific interethnic relations. Thus, the policy of multiculturalism becomes an important component of its public policy, assuming a tolerant attitude of political power to the issue of adapting of different ethnic groups to national norms, alleviating the historical tension between civic culture and ethnic culture. The purpose of multiculturalism is to establish an open society in which representatives of all groups (social, cultural, ethnic) have opportunities for self-development, self-actualisation, while preserving the unique cultural origin. Multiculturalism is seen in the USA as a democratic policy of addressing the problems of cultural and social diversity in a society that includes educational, linguistic, economic and social components and has specific mechanisms for implementation. The educational component is implemented in multicultural education, with BIE at the forefront [9].

At the end of the 20th century, there was an increase in the number of educational centers that offerred special training for teachers to participate in bilingual programmes. Specialisations «English as a second language (ESL) teacher», «Bilingual teacher» were introduced in pedagogical colleges. During this period, the National Association of Bilingual Education, the National Council of Teachers of English, the Association of Pedagogical Colleges, etc. were established. The Research Center for Multicultural Education at Colorado State University was among the first to focuse on the challenges of bilingual education and the introduction of innovative techniques and technologies into the learning process of foreign language learners [6].

The state has recognised the benefits and opportunities that bilingualism can give students in the future. It has strongly stated a course in multicultural education that recognises the right of ethnic groups to self-determination, preserving their culture, traditions and language. The American society gradually came to rethink the concept of «melting pot». This period was characterised by the development and rise in popularity of immersion programmes - Two-way immersion programmes (dual bilingual programmes) and Late-exit programmes - programmes which imply the use of two languages in combination classes where migrant students studied with the English-language students. The latter provided for separate education of foreign language students in a programme designed for the continuous teaching of subjects in the native language with a gradual increase in the share of English. But at the same time, a student had the opportunity to remain in this form of study after reaching the level required for the study with the English-speaking peers.

The results of conducted analysis of scientific sources allow concluding that the official system of BIE in the USA is the use of two languages, one of which is English, as a means of learning for the same group of students by a clearly organised programme that covers the whole curriculum or part of it, including the teaching of history and culture of the mother tongue. This programme is called to develop a sense of self-worth of children and pride in belonging to both cultures. As can be seen from the definition, the emphasis is placed not only on the functional learning of a language, but also on the cultural component, which makes it possible to interpret the BIE as a bicultural one $[10 ; 11]$.

Numerous models, programmes and definitions of BIE, particularly valuable in terms of understanding the essence of BIE in the system of multicultural education, are presented in American scientific sources. Diaz [12] outlines BIE as a curriculum aimed at using two languages of explanation in the process of obtaining education. This definition is quite broad and includes many variations. For example, a child who speaks Spanish can learn basic subjects in the native language while learning English as a second language (ESL). This approach is based on the idea that students' native language and culture can make a significant contribution to their education.

In the USA, the primary purpose of BIE is to develop English language competencies and literacy. Therefore, ESL is a necessary component of all bilingual programmes aiming to explain the content of the subject in the native language. However, when isolated, ESL introduction cannot be considered as BIE because the student's mother tongue is not used to explain the material taught. Students enrolled in this programme may fall behind other subjects because they do not fully understand the explanation. Their training can only be reduced to learning English as long as they do not learn to use it fully in life.

As validated by the Center for Educational Research, Diversity and Exellence of the U.S. Department of Education, a BIE programme is more effective than just an ESL programme, and not just in terms of learning English. Students possess knowledge based on previous literacy experience, but this situation is not typical of ESL programmes, since the training is mainly based on the study of the English grammar, phonetics and aspects of linguistics, outside the context of everyday use.

Depending on the structure and purpose of bilingual programmes, Sidun [13] distinguishes two forms of BIE:

(I) «weak» - transitional programmes - when the aim of bilingual programme is to switch to the second language of teaching only. Students are explained the content of the subjects in their native language and learn English as a foreign language. As soon as they are considered to be ready (usually within $2-5$ years) to switch to a monolingual programme, they are immediately transferred from bilingual programmes to the mainstream. They apply to their mother tongue only for the quickest possible transition to the learning in English. Nevetheless, it is necessary to maintain and develop a child's level of mother tongue in order to maintain the quality of education. Restricting the importance of the native language slows down the overall development and mastery of the programme. Transition programmes are only possible if the common feature of the audience is the poor command of language of teaching (state language). Having joined the mainstream, students are taught only in the state language. Such a temporary programme is characterised by a defined language hierar- 
chy, when the concepts of school language and home (community) language are enshrined in the child's mind. Although a school to the extent possible draws attention to the child's native culture, traditions and sources, these actions are at best reduced to some supportive theory - the real development of the native culture is not observed. Within transitional programmes, two teachers usually work with a class, or there are assistants to help children to overcome purely language problems.

(II) «strong». Here we differentiate:

(i) developmental bilingual education programmes - provide a more long-term and conscious approach. Just like in the transition model, students are encouraged to learn the subjects in their native language, while learning English as a second language. The difference is that students are not set a time frame for participation in the programme. The goal is to develop communicative competence in two languages by using both languages to teach the subjects. The longer students stay in the programme, the more bilingual they become. The curriculum is balanced and students study the subjects in the equal proportion in both native and English languages. This model is intended for both ethnic minority children and national minorities with its main feature - careful attitude towards the native language (language shelter), which in the first years of study is given priority, which prevents the loss of national and cultural identity in children. Critics of developmental programmes often accuse them of becoming too familiar with the second language and foreign language culture, which significantly complicates integration of children into the dominant sociocultural environment and further interaction with the society as a whole.

(ii) two-way bilingual education programmes - a bilingual model that provides students with academic education in at least two languages. At the same time, the quality of education should be so high as to guarantee the graduate a fulfilling future in a modern, at least bilingual environment. This model offers compatible teaching of English-speaking students and students who speak a different language. The purpose of these programmes is to develop bilingual competence, increase academic performance, positive cross-cultural perceptions and student behaviour. This model involves the joint educa- tion, the widespread use of mentoring and tutoring, since it is believed that each student has specific knowledge and skills that he / she should share with classmates. As a rule, these programmes have no time constraints, but sometimes a two-pronged approach can be part of a transitional programme and thus acquire all its characteristics. This model serves to preserve the linguistic heritage and diversity of the state, as well as to improve relations between representatives of core and non-core linguistic groups.

(iii) maintenance bilingual programmes - support students' ability to speak, read and write in their native language while learning English. For example, a student who speaks Spanish can enter school knowing satisfactorily English. Knowledge of Spanish does not mean that a child can read and write on it, as many English-speaking children cannot read and write when they enter school. At the initial stage of study, all lessons are taught in the students' native language, and in parallel they learn English. After the students have acquired sufficient knowledge of English, the lessons are taught in both native and English languages. One of the strongest arguments made by professionals in favour of this model is the fact that students will be better able to learn English if they are already able to read and write in their native language. Many Mexicans, Puerto Ricans, and Indians believe that maintenance bilingual programmes play a significant role in preserving their culture.

Conclusions. Intercultural communication is not a completely new research area, but in the globalised world its importance grows. Educational establishments attach a lot of importance to the issues of interculturality in a multinational society. BIE is a purposeful process of engaging in the world culture by means of native and foreign languages, when a foreign language acts as a means of knowing the world, acquiring of special knowledge, learning the cultural, historical and social experience of different countries and peoples. BIE is a great attempt to make society more aware of importance of effective intercultural interaction. Therefore, it is very important for the national science and practice to study the pros of BIE allowing an individual to develop and ensure the effective intercultural interaction in a multicultural society. Thus, it is the prospect for the furthe research.

\section{Список використаної літератури}

1. Hall E.T. The silent language. Westport, Conn.: Greenwood Press, 1980. 217 p.

2. Hammer M.R, Bennett M.J., Wiseman R. Measuring intercultural sensitivity: The intercultural development inventory. International Journal of Intercultural Relations. 2003. No 27. PP.421-447.

3. Nesdale D, Robbé M. De V., Van Oudenhoven J.P. Intercultural Effectiveness, Authoritarianism, and Ethnic Prejudice. Journal of Applied Social Psychology. 2012. № 42 (5). PP.1173-1191.

4. Matveev A.V., Nelson P. E. Cross cultural communication competence and multicultural team performance: Perceptions of American and Russian Managers. International Journal of Cross Cultural Management. 2004. No4 (2). PP. 253-270.

5. Bartosh O. Intercultural competence as a part of professional qualities. Logos. 2020. No 104. PP. 148-155.

6. Baker C. Foundations of bilingual education and bilingualism (4th ed.). Clevedon, England: Multilingual Matters, 2006.318 p.

7. Banks J.A. Cultural diversity and education: foundations, curriculum and teaching. London: Routledge, $2016.366 \mathrm{p}$

8. Gollnick D.M., Chinn Ph. C Multicultural Education in a Pluralistic Society ( $8^{\text {th }}$ ed). New Jersey: Pearson, 2008. $464 \mathrm{p}$

9. Parker W.C. Education for democracy: contexts, curricula, assessments. The Ohio State University: Information Age Publishing, 2002. $242 \mathrm{p}$

10.Callahan R., Gandara P.C. The bilingual advantage: language, literacy and the US labor market. Bristol: Multilingual Matters, 2014. $320 \mathrm{p}$

11.Snow C. The myths around bilingual education. NABE News. 1997. No 21 (2). PP. 29-35.

12.Díaz C.P. Multicultural education in the twenty-first century (1st ed.). New York: Allyn \& Bacon, 2000. $256 \mathrm{p}$

13.Сідун Л.Ю. Розвиток полікультурної освіти у вищій школі США: дис. ... канд. пед. наук: 13.00 .04 / Тернопільський національний педагогічний університет імені В. Гнатюка. Тернопіль, 2021. 192 с.

\section{References}

1. Hall, E.T. (1980). The silent language. Greenwood Press.

2. Hammer, M.R, Bennett, M.J., \& Wiseman, R. (2003). Measuring intercultural sensitivity: The intercultural development inventory. International Journal of Intercultural Relations, 27, 421-447.

3. Nesdale, D, Robbé, M. De V., \& Van Oudenhoven, J.P. (2012). Intercultural Effectiveness, Authoritarianism, and Ethnic Prejudice. Journal of Applied Social Psychology, 42 (5), 1173-1191.

4. Matveev, A.V., \& Nelson, P.E. (2004). Cross cultural communication competence and multicultural team performance: Perceptions of American and Russian Managers. International Journal of Cross Cultural Management, 4 (2), $253-270$. 
5. Bartosh, O. (2020). Intercultural competence as a part of professional qualities. Logos, 104, 148-155.

6. Baker, C. (2006). Foundations of bilingual education and bilingualism (4th ed.). Multilingual Matters.

7. Banks, J.A. (2016). Cultural diversity and education: foundations, curriculum and teaching. Routledge.

8. Gollnick, D.M., \& Chinn, Ph.C. (2008). Multicultural Education in a Pluralistic Society (8 ${ }^{\text {th }}$ ed). Pearson.

9. Parker, W.C. (Ed.). (2002). Education for democracy: contexts, curricula, assessments. Information Age Publishing.

10.Callahan, R., \& Gandara, P.C. (Eds.). (2014). The bilingual advantage: language, literacy and the US labor market. Multilingual Matters.

11.Snow, C. (1997). The myths around bilingual education. NABE News, 21 (2), 29-35.

12.Díaz, C.P. (Ed.). (2000). Multicultural education in the twenty-first century (1st ed.). Allyn \& Bacon.

13.Sidun, L.Yu. (2021). Rozvytok polikul'turnoyi osvity u vyshchiy shkoli SSHA [Development of multicultural education in US higher education] [Unpublished Candidate dissertation]. V.Hnatiuk Ternopil National Pedagogical University. [in Ukrainian].

Стаття надійшла до редакції 15.03.2021 p. Стаття прийнята до друку 20.03.2021 р.

\section{Бартош Олена Павлівна}

кандидат педагогічних наук, доцент

кафедра соціології та соціальної роботи

ДВНЗ «Ужгородський національний університет», м.Ужгород, Україна

\section{БІЛІНГВАЛЬНЕ НАВЧАННЯ ЯК ВАЖЛИВА УМОВА ЗАБЕЗПЕЧЕННЯ ЕФЕКТИВНОЇ МІЖКУЛЬТУРНОЇ ВЗАСМОДІЇ В АМЕРИКАНСЬКОМУ БАГАТОНАЦІОНАЛЬНОМУ СУСПІЛЬСТВІ}

Анотація. Міжкультурна комунікація - не зовсім нова сфера досліджень, але у глобалізованому світі ііі значення зростає. Навчальні заклади надають великого значення питанням міжкультурності в багатонаціональному суспільстві. Білінвальне міжкультурне навчання - це цілеспрямований процес залучення до світової культури за допомогою рідної та іноземних мов, коли іноземна мова виступає як засіб пізнання світу, набуття спеціальних знань, засвоєння культурного, історичного та соціального досвіду різних країн та народів. Американські вчені розглядають впровадження полікультурної освіти, зокрема двомовної міжкультурної освіти, як один із перспективних способів забезпечення ефективної міжкультурної взаємодії. Метою статті $\epsilon$ аналіз та узагальнення ідей американського досвіду білінгвальної освіти як засобу забезпечення ефективної міжкультурної взаємодії в багатонаціональній державі. Використані методи дослідження: аналіз та систематизація педагогічних робіт, які дозволили виявити концептуальні міркування щодо двомовної міжкультурної освіти як важливої передумови ефективної міжкультурної взаємодії; спостереження та викладацький досвід автора. Наукова новизна полягає в обгрунтуванні суттєвих характеристик двомовної міжкультурної освіти та iii ролі у забезпеченні міжкультурної взаємодії в багатонаціональному суспільстві. Білінвальне міжкультурне навчання - цілеспрямований процес долучення до світової культури засобами рідної та іноземної мов, коли іноземна мова виступає як засіб пізнання світу, здобуття спеціальних знань, засвоєння культурно-історичного та соціального досвіду різних країн та народів. Для вітчизняної науки і практики доцільним є використання ідей зарубіжного досвіду білінгвального міжкультурного навчання. Ми розглядаємо двомовну міжкультурну освіту такою освітньою організацією, коли стає можливим використовувати більше однієї мови як мови викладання. Отже, друга мова $є$ не лише об'єктом вивчення, а й засобом спілкування та мовою навчання. Основна відмінність між полікультурною освітою та традиційною освітою полягає в тому, що сама мова викладання є не лише інструментом викладання та навчання, але і іiі призначенням.

Ключові слова: міжкультурна взаємодія; багатонаціональне суспільство; білінгвальне міжкультурне навчання; полікультурна освіта; зарубіжний досвід. 